\title{
NUMBER AND DISTRIBUTION OF GYRFALCONS ON THE WEST SIBERIAN PLAIN
}

\author{
IRINA Pokrovskaya ANd GRIgory TeRTITSKI
}

Institute of Geography, Russian Academy of Sciences, 29 Staromonetny per., Moscow, 119017, Russia.E-mail: savair@yandex.ru

\begin{abstract}
Using our own observations and published records, we discuss the breeding range, number, and distribution of Gyrfalcons (Falco rusticolus) on the West Siberian plain. We show that the currently accepted assessment of Gyrfalcon numbers appears to be underestimated. The southern limit of the species' breeding range should be defined south of forest-tundra. With the predicted northward expansion of forest due to climate change, West Siberian and neighboring Gyrfalcons of subspecies F.r. intermedius appear preadapted to such habitat and may be favored by its expansion. These considerations call for increased efforts to survey the region for the presence of nesting Gyrfalcons. Received 22 March 2011, accepted 23 May 2011.
\end{abstract}

Pokrovskaya, I., AND G. Tertitski. 2011. Number and distribution of Gyrfalcons on the West Siberian Plain. Pages 267-272 in R. T. Watson, T. J. Cade, M. Fuller, G. Hunt, and E. Potapov (Eds.). Gyrfalcons and Ptarmigan in a Changing World, Volume II. The Peregrine Fund, Boise, Idaho, USA. http://dx.doi.org/10.4080/gpcw.2011.0305

Key words: Gyrfalcon, West Siberian Plain, breeding range, forest-tundra, taiga.

FOR EFFECTIVE INTERNATIONAL MANAGEMENT OF GyRFALCONS (FALCO RUSTICOLUS), an accurate estimate of the abundance and distribution of the species in Russia is important because Russia contains the largest part of the species' world range. The National Red Book of Russia (Danilov-Danilian 2001) estimates the number of Gyrfalcons in Russia as a whole to be 1,000 pairs. However, during the last decade, the number of Gyrfalcons was estimated at about 600 pairs at least, at two long-term monitoring sites in southern Yamal and northern Kamchatka peninsula (Mechnikova et al. 2011, Lobkov et al. 2011). The current information suggests that the Red Book data may need to be updated.

The monitoring site in southern Yamal Peninsula is located in part of the West Siberian
Plain. Approximately $25-50$ breeding pairs nest there in forest-tundra habitat in a study area of $28,000 \mathrm{~km}^{2}$ (Figure 1, site 1). This is the highest reported density of Gyrfalcons in the world at about 12.2 pairs per $1,000 \mathrm{~km}^{2}$ (Mechnikova et al. 2008). However, the distribution and abundance of Gyrfalcons on the remaining part of the West Siberian Plain has never been well understood. Potapov and Sale (2005) provided only a few words about the Gyrfalcon in this extremely large plain.

The West Siberian Plain covers the prominent part of the breeding, migrating and wintering range of the Gyrfalcon in the center of the Palearctic region. It is situated between the Ural Mountains to the west and the Yenisei River to the east, and occupies 2,745,000 $\mathrm{km}^{2}$. The plain is poorly drained and consists of 


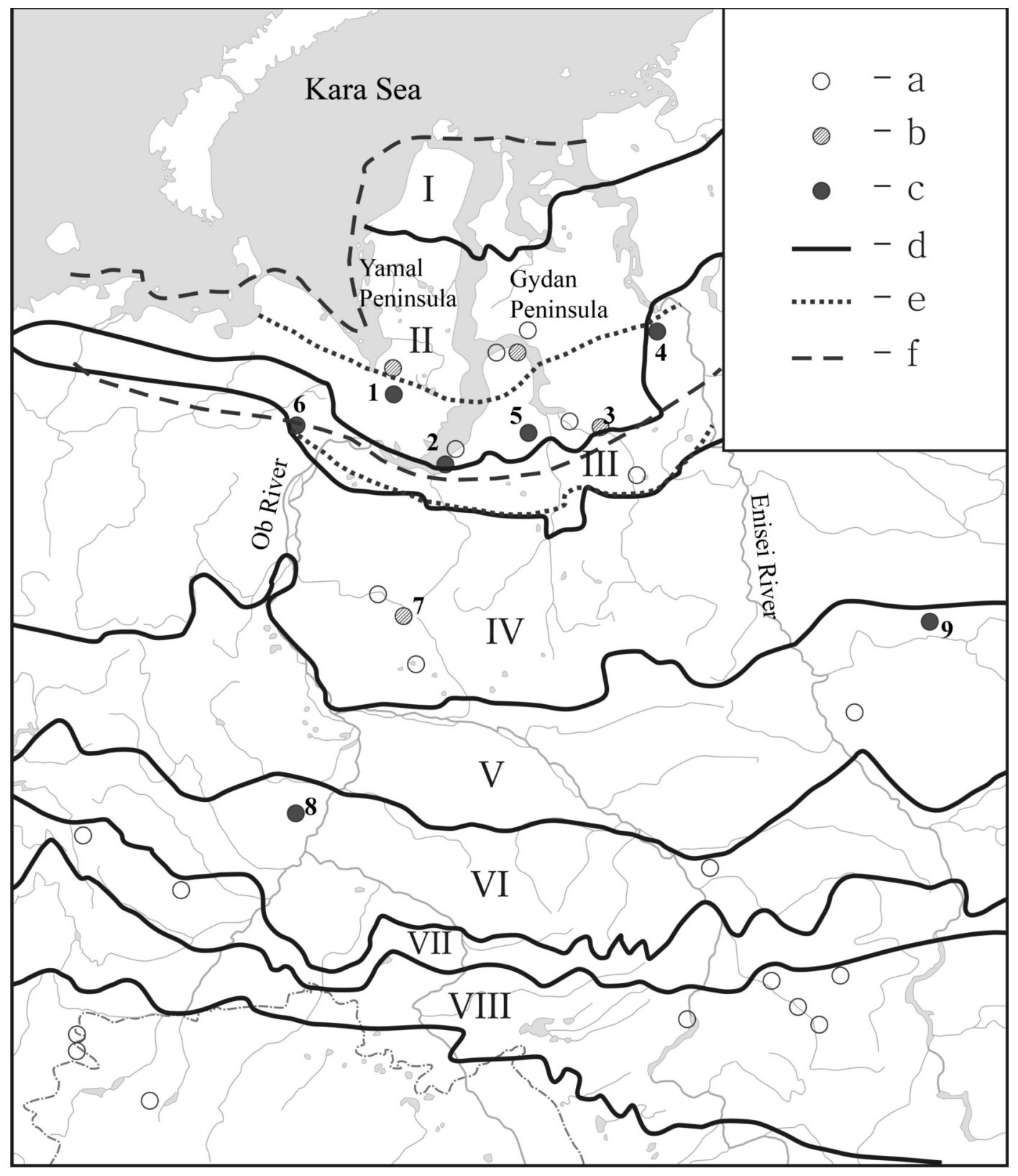

Figure 1. Range and records of Gyrfalcon at the West Siberian Plain. Vegetation zones and subzones:

I arctic tundra

II subarctic tundra

III forested tundra

IV boreal forest, northern subzone

$\checkmark$ boreal forest, central subzone

VI boreal forest, southern subzone

VII forested steppes

VIII real steppes a records of non-breeding birds

b possible breeders

c confirmed breeders

$d$ boundaries of vegetation zones and sub-zones

e up-dated boundaries of the Gyrfalcon distribution range

$f$ boundaries of the Gyrfalcon range of distribution

(Red-data Book of the Russian Federation) 
some of the world's largest floodplains and swamps that are characterized by raised bogs. The plain has eight distinct latitudinal vegetation zones: arctic tundra, subarctic tundra, forested tundra, boreal forest (taiga) northern, central, and southern subzones, forested steppe, and steppe (Figure 1). Even in the taiga zone, oligotrophic bogs comprise from 40 to 75 percent of the landscape. These bogs strike into the tundra zone to the north, and southwards into timberline habitats of the taiga zone with a huge area south of the northern forest boundary. They create open areas in the boreal forest that connect with the open tundra and can be used by some arctic and subartic species, like the Gyrfalcon, to expand their range to the south.

In the regional Red Book of the YamaloNenetsky autonomous administrative district (Bolshakov 1997), which covers the northern part of West Siberia from the River Ob to the Yenisei River and includes $750,000 \mathrm{~km}^{2}$, the total number of nesting Gyrfalcons was estimated at about 30-40 pairs. According to Krivenko et al. (2008), the total number of Gyrfalcons in this part of western Siberia was 180 individuals at the end of the breeding period. This number, which presumably includes young of the year, is close to the regional Red Book estimate. However, the entire number of Gyrfalcons at the southern Yamal monitoring site was estimated as $25-50$ breeding pairs (Mechnikova et al. 2011). If they accounted for all the Gyrfalcons breeding in West Siberia, then the remaining huge territory of the West Siberian Plain should be free of Gyrfalcons. Although Gyrfalcon nest records in the remaining area of the West Siberian plain were extremely sparse, we provide our own observations and published records to illustrate that they may be more common than previously thought.

\section{RESULTS AND DisCuSSION}

We investigated areas of possible Gyrfalcon nesting in the West Siberian Plain and found two successfully breeding pairs on the coastal part of forest-tundra in the very south of Obskaya Guba Bay (River Ob estuary) in 1987 (Figure 1, site 2). This area is situated not far $(380 \mathrm{~km})$ to the southeast of the southern Yamal monitoring site, but separated by the huge floodplain of the $\mathrm{Ob}$ River and $\mathrm{Ob}$ Gulf. The two nests were situated $5 \mathrm{~km}$ apart along the Lenzita River in the northern foresttundra zone. This inter-nest distance is the minimum for breeding Gyrfalcons. One nest was situated in the old nest of a White-tailed Eagle (Haliaeetus albicilla) on an old larch tree. There were three nestlings and a pair dark morph adults. The behavior of the parents was quite aggressive. The young birds left the nest on 5 July. An oil-drilling station was being constructed about $2 \mathrm{~km}$ away and noise contamination was very high, yet we did not notice any negative reaction of the birds. The second nest was found later at the very end of June. It was situated on an old geodesic tower. Both parents were also dark morph birds. The nest material was sparse and there were two nestlings, much younger than in the first nest, which left the nest on 30 July. The density of Willow Ptarmigan (Lagopus lagopus) was rather high that year.

Searches for Gyrfalcons over three summermonths in 1986 to the east of the plain along the Taz River near its crossing with the Polar Circle were in vain. However, in 2002, Gyrfalcons were found presumably breeding at the lower end of the Taz River, further north at the confluence with the Russkaya River (Figure 1, site 3; Vinogradov 2002). A Gyrfalcon nest site was reported at the border of the forest-tundra and subarctic tundra, or timberline, at the very east of West Siberia, on the left tributary of the Enisei - Malaya Khetta River (Figure 1, site 4; Telegin 1973).

Whether or not Gyrfalcons nest on the Gydan Peninsula, situated in the northeasternmost tundra zone of the West Siberian Plain, is open for further investigation. At the end of the last century, regional hunt manager G. Chuvashov 
investigated the negative influence of trappers hunting raptors, including Gyrfalcons (Chuvashov 1989). For every $100 \mathrm{~km}$ of trap line, five Gyrfalcons were caught in winter on the Gydan Peninsula in the subarctic tundra zone. This fact indicates a high density of Gyrfalcons in the area at a time when Gyrfalcons may be expected to be in their breeding sites. Previously, arctic tundra breeding Gyrfalcons were considered to be absent from the north of both the Yamal and Gydan peninsulas (Danilov et al. 1984).

In 1938, a Gyrfalcon was found breeding in the forest-tundra zone on the small Tazovsky Peninsula on the River Khadutte (Figure 1, site 5; Dementiev 1951). In 2005, E. Loktionov (pers. comm.) found Gyrfalcons nesting in the Polar Ural mountains in the Sob River basin (Figure 1, site 6).

For a long time, the intriguing question about the southern limit of the Gyrfalcon's breeding range on the West Siberian Plain was unclear. In the 1920s, ornithologist V. Larionov made an inventory of avifauna in the Tumen region (Larionov 1926), between $56^{\circ}$ and $58^{\circ} \mathrm{N}$ and on the boundary between the southern taiga subzone and forest-steppe zone. The region included vast open areas of swamp. Larionov included the Gyrfalcon in the bird species check-list as not only migrating and wintering, but also as a nesting species. He indicated the habitat of the Gyrfalcon was pine-tree forest.

On 9 August 1937, in the Surgut district on the Torm-Yaun River, A. Sharonov observed a brood of recently fledged Gyrfalcons flying well, and collected one of the birds (Figure 1, site 7; Sharonov 1951). Now this bird is in the collection of the Zoological Institute at SaintPetersburg. In his book "The Gyrfalcon," the famous Russian ornithologist and falcon expert G. Dementiev entertained the possibility of Gyrfalcons breeding in the forest zone in biotopes resembling timberline (Dementiev 1951). Later, however, Siberian ornithologist N. Danilov considered that the mention of Gyrfalcons breeding in the Tyumen District (Lari- onov 1926) and in the Surgut region (Sharonov 1951) had been erroneous (Danilov 1969).

The question about taiga nesting Gyrfalcons was open and unclear until 2005, when Sorokin recorded the breeding of Gyrfalcons on the huge marshes in the mid-boreal forest subzone (Figure 1, site 8; Sorokin 2009). The landscape looks like forest-tundra at this nest site. The nest was originally built by an Imperial Eagle (Aquila heliaca) in a Stone Pine tree (Pinus sibirica). This finding confirms the suggestion by Dementiev that Gyrfalcons may breed in the taiga zone, in landscapes that resemble forest-tundra. Such timberline-like landscapes are distributed widely in West Siberia and far to the south due to enormous areas of swamp that open the otherwise forested landscape.

Further eastwards from Western Siberia, Gyrfalcons were recorded breeding on the River Nizhnyaya Tunguska, far to the south of the southern limit of their breeding range (Tkachenko 1937). This area was home to a pair of Gyrfalcons almost 100 years ago in 1918. In 1988, 70 years later, a Gyrfalcon was observed in summer on a rock on the same river. Further west of Western Siberia, Gyrfalcons bred in the Ural Mountains far to the south on the Ufa and Chusovaya Rivers until the middle of the $19^{\text {th }}$ century (Danilov 1969).

Based on these observations it seems quite possible that the southern limit of the Gyrfalcon's breeding area should be extended to the south, and future ornithological investigations should seek to confirm this suggestion. It is necessary to pay special attention to record maximum details in the case of summer observations of Gyrfalcons in the taiga zone.

With the predicted northward expansion of forest due to climate change, West Siberian and neighboring Gyrfalcons of subspecies $F$. $r$. intermedius may be pre-adapted to such habitat and favored by its expansion. These considerations call for increased efforts to survey the region for the presence of nesting Gyrfalcons. 


\section{Literature Cited}

Bolshakov, V. N. (Ed.). 1997. Red Book of Yamalo-Nenetsky Autonomous District. Ekaterinburg, Russia (in Russian).

Chuvashov, G. I. 1989. Death of rare species of falcons and other birds of prey on Gydan Peninsula. Pages 73-76 in All-Union Meeting on problem of Cadastre and Count of Wildlife, part 3. Ufa, Russia (in Russian).

Danilov, N. N. 1969. Birds of the Middle and Northern Ural. History of study of birds of the Ural. Orders Gaviiformes, Podicepediformes, Pelecaniformes, Ciconiiformes, Anseriformes and Falconiformes. Proceedings of the Ural Department of Moscow Naturalist's Society. Sverdlovsk 3:3-123 (in Russian).

DANILOV, N. N., V. N. RYZHANOVSKIY, AND V. K. Ryabitsev. 1984. Birds of Yamal. Nauka, Moscow, Russia (in Russian).

Danilov-Danilian, V. I. (Ed.). 2001. Red Data Book of the Russian Federation (Animals). AST-Astrel, Moscow, Russia (in Russian).

Dementiev, G. P. 1951. The Gyrfalcon: Systematic, distribution, life history and practical value-Moscow Society of Naturalists, Zoological Branch, Issue 29. Moscow, Russia (in Russian).

Krivenko V. G., E. S. Ravkin, AND M. V. MiRUTENKO. 2008. Catalogue of raptor numbers in the Yamal-Nenetsky region. Pages 16-18 in Research and Conservation of the Raptors in Northern Eurasia: Proceedings of the $5^{\text {th }}$ Conference on Raptors of Northern Eurasia. Ivanovo, Russia (in Russian).

LARIONOV, V. F. 1926. Check-list of the birds in Tyumen region. Pages 185-196 in Proceedings of the Tomsk University, vol. 77(3). Tomsk, Russia (in Russian).

Lobkov, E., Yu. Gerasimov, AND A. GorovenKo. 2011. Status of the Kamchatka Gyrfalcon (Falcon rusticolus) population and factors affecting it. In R. T. Watson, T. J. Cade, M. Fuller, G. Hunt, and E. Potapov (Eds.). Gyrfalcons and Ptarmigan in a Changing World. The Peregrine Fund, Boise, Idaho, USA. http://dx.doi.org/ 10.4080/gpcw.2011.0127
Mechnikova, S. A., V. N. Kalyakin, M. S. Romanov, AND N. V. KudRYAVTSEV. 2008. Long-term dynamics of Falco rusticolus nest size and brood size in the South of Yamal Peninsula. Pages 229-230 in Proceedings of the $2^{\text {nd }}$ International Conference "Mathematical Biology and Bioinformatics," Pushchino, Russia, September 7-13, 2008. MAKS-Press, Moscow, Russia (in Russian).

Mechnikova, S. A., M. Romanov, And N. KudRYAVTSEV. 2011. Change in numbers and nesting ecology of the Gyrfalcon in Yamal Peninsula, Russia, from 1981 to 2010. In R. T. Watson, T. J. Cade, M. Fuller, G. Hunt, and E. Potapov (Eds.). Gyrfalcons and Ptarmigan in a Changing World. The Peregrine Fund, Boise, Idaho, USA. http://dx.doi.org/10.4080/gpcw.2011.0220

Potapov, E., ANd R. SAle. 2005. The Gyrfalcon. T. \& A. D. Poyser, London, UK.

Sharonov, A. D. 1951. Some results on bird study in the taiga zone of Western Siberia. Proceedings of the USSR Academy of Science, vol. 78(5) (in Russian).

Sorokin, A. G. 2009. Kondo-Alymskaya ornithological anomaly, Russia. Raptors Conservation 15:90-96 (in Russian).

Stepanyan, L. S. 2003 Conspectus of the ornithological fauna of Russia and adjacent territories (within the borders of the USSR as a historic region). Academkniga, Moscow, Russia (In Russian).

Telegin, V. I. 1973. Notes of raptors nesting in the north of Western Siberia. In Nature of the Taiga in Western Siberia. Nauka, Novosibirsk, Russia (in Russian).

TкаснEnko, M. I. 1937. Birds of the Lower Tunguska River. Pages 152-162 in Proceedings of the Society on Research of Eastern Siberian District, vol. 2(57). Irkutsk, Russia.

Vinogradov, V. G. 2002. The birds of the Russkaya (Luce-Yaha) River and lower course of the Taz River. Pages 72-85 in Materials of bird distribution at Ural, Priural'e and Western Siberia. Akademkniga, Ekaterinburg, Russia (in Russian). 
- POKROVSKAYA AND TERTITSKI - 